\title{
Nutrient addition does not enhance leaf decomposition in a Southeastern Brazilian stream (Espinhaço mountain range)
}

\author{
Abelho, M. ${ }^{\mathrm{a}, \mathrm{b} *}$, Moretti, M. ${ }^{\mathrm{c}}$, França, $J .^{\mathrm{c}}$ and Callisto, $M .^{\mathrm{c}}$ \\ ${ }^{a}$ Escola Superior Agrária, Instituto Politécnico de Coimbra, CEP 3040-316, Coimbra, Portugal \\ 'IMAR-Centro do Mar e Ambiente (CMA), Portugal \\ 'Laboratório de Ecologia de Bentos, Departamento de Biologia Geral, \\ Universidade Federal de Minas Gerais - UFMG, CP 486, CEP 30161-970, Belo Horizonte, MG, Brazil \\ *e-mail: abelho@esac.pt
}

Received December 7, 2009 - Accepted February 22, 2010 - Distributed October 31, 2010

(With 5 figures)

\begin{abstract}
A decomposition experiment using eucalyptus leaves was carried out in a Southeastern Brazilian mountain stream located at the transition between the Cerrado and the Atlantic Forest to test whether nutrient addition increases microbial and invertebrate colonisation and accelerates breakdown rates. The results show that none of the tested variables was significantly affected by nutrient addition, despite the average increase in ATP concentrations and invertebrate colonisation observed in the fertilised leaf bags. This could mean that breakdown in the stream was already at its maximum due to the relatively high water temperature and nutrient content, or that the breakdown rate of eucalyptus leaves was too fast to allow the detection of any effects of nutrient addition. Breakdown rates of eucalyptus leaves were much faster than the values reported in literature for most species in Brazilian Cerrado streams, suggesting that the replacement of the natural vegetation by eucalyptus may affect nutrient dynamics in the region.
\end{abstract}

Keywords: eucalyptus leaf breakdown, nutrients, ATP concentrations, macroinvertebrates, tropical stream.

\section{A adição de nutrientes não acelera a decomposição de folhas em um riacho do Sudeste do Brasil}

\section{Resumo}

Um experimento de decomposição de folhas de eucalipto foi efetuado em um riacho do sudeste do Brasil, localizado na transição entre o Cerrado e a Mata Atlântica para testar se a adição de nutrientes aumenta a colonização das folhas por microrganismos e por invertebrados e se acelera a sua taxa de decomposição. Nenhuma das variáveis testadas foi significativamente afetada pela adição de nutrientes, apesar do aumento médio verificado nas concentrações de ATP e na colonização por invertebrados dos sacos contento detritos fertilizados. Isto pode significar que a decomposição no riacho já ocorria à taxa máxima devido à temperatura e concentração de nutrientes relativamente elevadas da água ou que a taxa de decomposição das folhas de eucalipto foi demasiado rápida para permitir detectar qualquer efeito da adição de nutrientes. Os coeficientes de decomposição das folhas de eucalipto $\left(0,1127-0,1192\right.$ dia $\left.^{-1}\right)$ foram mais elevados que os verificados na literatura para a maioria das espécies em riachos do Cerrado, sugerindo que o reflorestamento com eucalipto pode alterar a dinâmica dos nutrientes na região.

Palavras-chave: decomposição de folhas de eucalipto, nutrientes, concentração de ATP, macroinvertebrados, riacho tropical.

\section{Introduction}

The effects of dissolved nutrients on rates of leaf decomposition, fungi and macroinvertebrates colonising the leaves may involve complex interactions, and several nutrient enrichment experiments have produced varying results. For instance, Robinson and Gessner (2000) found no differences in fungal biomass or activity between fertilised and unfertilised leaf packs, suggesting that the faster breakdown of fertilised leaf packs was brought about by increased shredder colonisation and feeding. Royer and Minshall (2001) showed that breakdown rates of three leaf species were unaffected by nutrient enrichment, suggesting that leaf breakdown was not nutrient-limited in that stream. Abelho and Graça (2006) also found no differences in breakdown rates, fungal biomass, and 
macroinvertebrate colonisation in nutrient-enriched leaf packs; however, sporulation rates of aquatic hyphomycetes were stimulated by the addition of $\mathrm{N}$ (either alone or with $\mathrm{P}$ ), but not $\mathrm{P}$ alone.

Leaf litter decomposition has been the subject of numerous studies in temperate streams of the northern hemisphere (Abelho, 2001). With the exception of Australia, little is known about the process, especially regarding microbial colonisation and activity, in the southern hemisphere. In the Brazilian Cerrado (tropical savannah), leaf decomposition is in general slow, at least for streamorders up to 3 (Gonçalves Jr., 2005; Gonçalves Jr. et al., 2006, Moretti et al., 2007 a, b), despite the relatively high water temperatures during the local summer (January to March). The slow breakdown rates have been attributed to the scarcity of shredders in some streams (Gonçalves Jr., 2005; Gonçalves Jr. et al., 2007) but mainly to the type of leaf litter natural of the area (Gonçalves Jr., 2005; Moretti, 2005; Gonçalves Jr. et al., 2007; Moretti et al., 2007a). In fact, natural leaf litter of the Brazilian Cerrado is in general tough, with low amounts of nutrients and relatively high amounts of secondary compounds, such as polyphenols (Gonçalves Jr. et al., 2007; Moretti et al., 2007a). On the other hand, natural vegetation of the Atlantic Forest has shown faster decomposition rates than the Cerrado vegetation (Ribas et al., 2006).

Extensive areas of the Brazilian territory, including the Cerrado, have been replanted with eucalyptus monocultures (Klink and Machado, 2005) for the purpose of paper production. In the Brazilian Cerrado, this afforestation has also been carried out in the riparian areas of some streams (Moretti, 2009). Experiments carried out in temperate streams (e.g. Abelho and Graça, 1996; Canhoto and Graça, 1996; Graça et al., 2002), where eucalyptus is also an introduced species, have shown that species of eucalyptus decompose relatively slow in comparison to the natural leaf litter in these streams. Although very few data is available on the decomposition rate of eucalyptus in Brazilian streams, the results obtained by Hepp et al. (2009) and Gonçalves Jr. (2005) for Eucalyptus grandis (0.0050 to 0.0068 day $^{-1}$ ) are within the higher range reported (Gonçalves Jr., 2005; Moretti et al., 2007a, b) for breakdown rates of natural vegetation of the Cerrado in several Southeastern Brazilian streams $\left(0.0019\right.$ to 0.0063 day $\left.^{-1}\right)$.

The main objective of this study was to assess whether nutrient availability may limit the process of leaf decomposition in a mountain stream located at the southern end of the Espinhaço Range Mountain, and, if so, whether macroinvertebrates, microorganisms, or both, mediate the effect.

\section{Material and Methods}

\subsection{Site description}

The study was conducted in Garcia stream, a third-order stream located at Serra do Ouro Branco (in the southern end of the Espinhaço Range Mountain), $100 \mathrm{~km}$ south of Belo Horizonte (Minas Gerais, Brazil: 20²1' S and $\left.43^{\circ} 41^{\prime} \mathrm{W}\right)$. According to the Koppen Climate Classification System, the climate in the area is mesothermic with dry winter $(\mathrm{Cwb})$, strongly seasonal with temperatures ranging from 13 to $22{ }^{\circ} \mathrm{C}$ (mean annual $17{ }^{\circ} \mathrm{C}$ ) and mean annual precipitation of $1,200 \mathrm{~mm}$. The vegetation ranges from Atlantic Forest (Mata Atlântica) at lower elevations to Cerrado at higher elevations, but along streams, where humidity is higher and soils are more fertile, the vegetation is tropical semi-deciduous seasonal forest (Giulietti et al., 1987). The selected stream is located at an altitude of $1,300 \mathrm{~m}$ a.s.l. and its drainage basin occupies an area of approximately $20 \mathrm{~km}^{2}$.

At each sampling date, immediate physicochemical parameters $(\mathrm{pH}$, specific conductance, dissolved oxygen and temperature) were measured in situ with WTW field instruments, and water samples were collected and analysed for orthophosphate and total nitrogen concentrations according to APHA (1998). The water was clear, with $\mathrm{pH}$ ranging from 7.08 to 7.59 , specific conductance from 27 to $30.7 \mu \mathrm{S} . \mathrm{cm}^{-1}$, dissolved oxygen from 7.2 to $9.0 \mathrm{mg} . \mathrm{L}^{-1}$, and water temperature from 18 to $19.3^{\circ} \mathrm{C}$. Orthophosphate concentrations ranged from $<0.010$ to $0.078 \mathrm{mg} . \mathrm{L}^{-1}$, and total nitrogen concentrations from 0.2 to $0.7 \mathrm{mg} . \mathrm{L}^{-1}$ (as $\mathrm{NO}_{2}+\mathrm{NO}_{3}+\mathrm{NH}_{4}$ ). Width of the channel at the study site was $3.5 \mathrm{~m}$, water depth varied from 13.6 to $16.6 \mathrm{~cm}$, current velocity (eight replicate measurements with a Swoffer Model 2100 Series Open Stream Current Velocity Meters) from 0.37 to $0.53 \mathrm{~m} . \mathrm{s}^{-1}$, and discharge from 0.18 to $0.27 \mathrm{~m}^{3} \cdot \mathrm{s}^{-1}$.

\subsection{Leaf decomposition experiment}

Leaf packs were made of eucalyptus (Eucalyptus camaldulensis Dehnh.) leaves previously collected from a single tree. The leaves were air-dried and kept at room temperature in the laboratory until used. In the day before incubation, the leaves were weighed ( $2.954 \mathrm{~g} \pm 0.030 \mathrm{SD})$, numbered (1-48), wetted to prevent damage during manipulation, and enclosed in coarse mesh bags $(10 \mathrm{~mm})$. Nutrients were added to half of the bags in the form of one slow-release fertiliser briquette containing $11 \% \mathrm{~N}$, $8 \% \mathrm{P}_{2} \mathrm{O}_{5}$, and $8 \% \mathrm{~K}_{2} \mathrm{O}$ (Agrofor Fertilizantes Ltda., CNPJ 21.193.586/0001-28) inserted into small $1 \mathrm{~mm}$ mesh bags. Eight leaf packs were oven-dried ( 3 days, $\left.60{ }^{\circ} \mathrm{C}\right)$ and weighed with a precision of $0.001 \mathrm{~g}$ to determine the average moisture content of leaves before the experiment. Average moisture, together with the initial air-dry mass of individual packs, was used to calculate the initial dry mass.

Pairs of bags with and without fertiliser briquettes were tied to steel rods anchored into the stream bottom on 24 January 2006. Four replicate leaf packs of each treatment were retrieved 1, 7, 14, 21, and 28 days after immersion, allocated to individual bags with stream water, stored in an ice-chest and returned to the laboratory.

The leaves were gently washed with tap water through a $250 \mu \mathrm{m}$ sieve to remove macroinvertebrates and attached debris. The macroinvertebrates were stored in $70 \%$ ethanol until identified (Pérez, 1988; Costa et al., 2006), counted, and classified into functional feeding groups: 1) shredders, 
2) scrapers and collectors, 3) filterers, and 4) predators (Merritt and Cummins, 1996). For the purpose of biomass estimations, the dipterans Chironomidae were not classified into functional feeding groups and were treated separately from the other invertebrates.

Two replicate sets of eight leaf discs $(\varnothing 11 \mathrm{~mm})$ were cut from each sample. One set of eight leaf discs was used to determine ATP concentrations associated with the leaves, according to the protocol described in Abelho (2005). The discs were homogenised (30 seconds, position 30 , Polytron homogeniser) in $5 \mathrm{~mL} 0.05 \mathrm{M}$ HEPES buffer (N-[2-Hydroxyethyl] piperazine-N-[2-ethanesulfonic acid]; C8H17N2O4SNa) and $5 \mathrm{~mL} 1.2 \mathrm{~N}$ sulphuric acid containing $8 \mathrm{mg} . \mathrm{L}^{-1}$ of oxalic acid, centrifuged (refrigerated centrifuge, $10 \mathrm{~g}$, 20 minutes), neutralized $\left(\mathrm{NH}_{4} \mathrm{OH}\right)$, and frozen at $-20{ }^{\circ} \mathrm{C}$. ATP was quantified with a luminometer using the firefly bioluminescence method. Absolute quantitative determinations of the amount of extracted ATP were made by measuring relative changes in light emission before and after the addition of internal standards during an integration period of 30 seconds. At least two readings were made on each sample. Final values were calculated on the basis of dry mass of the eight reference leaf discs (nmol.ATP. ${ }^{-1}$ dry mass). The values presented have been corrected for extraction efficiency in each session (70\%). Extraction efficiency in each session was determined by adding a known amount of ATP ( $5 \mathrm{nmol})$ to an extra sample of eight non-colonised, air-dried leaf discs. ATP concentrations were converted to microbial biomass using the conversion factors from Abelho (2009): $0.59 \mu$ mol.ATP. ${ }^{-1}$ fungal biomass (from day 0 up to the first decrease in ATP concentrations) and $1.30 \mu$ mol.ATP.g ${ }^{-1}$ bacterial biomass (from that point on).

The other set of eight leaf discs and the remaining leaf material were oven-dried $\left(3\right.$ days, $60{ }^{\circ} \mathrm{C}$ ). Dry mass remaining on each sample was calculated as the remaining mass plus two times the mass of the leaf discs. Exponential breakdown rates of leaves were estimated using linear regression on $\ln (\mathrm{x})$ transformed data.

Analysis of covariance (ANCOVA) was used to test for differences in breakdown rates between treatments (Boulton and Boon, 1991). Differences between treatments (ATP concentrations, macroinvertebrate abundance and biomass) were tested by two-way analysis of variance (ANOVA) on $\log (\mathrm{x}+1)$ transformed data, with time and treatment as factors and leaf bags as replicates. Differences between treatments in the percentage of functional feeding groups were tested by repeated measures analysis of variance on arcsine of the square root of the values, where the functional feeding groups are the multiple dependent variables measured at the different sampling dates. All statistical analyses were performed with the software STATISTICA 7.0 for Windows with the level of significance set at $\mathrm{p}<0.05$.

\section{Results}

Leaf breakdown rates were not significantly different (ANCOVA: $\mathrm{F}=0.078, \mathrm{df}=46, \mathrm{p}>0.05$ ) in leaf bags with and without added nutrients (Table 1). After 4 weeks in the stream, only $4.1 \%( \pm 1.4 \mathrm{SE})$ of the initial leaf mass remained in the fertilised bags, and $8.2 \%( \pm 3.7 \mathrm{SE})$ remained in the unfertilised bags (Figure 1).

ATP concentrations associated with decomposing leaves increased faster and average values were higher in the fertilised than in the unfertilised leaves during the whole study period, attaining a maximum of 106 and 74 nmol.ATP.g ${ }^{-1}$ dry mass remaining, respectively on day 7 in fertilised and on day 21 in unfertilized leaves (Figure 2). However, no significant differences were found between the two treatments (ANOVA: $\mathrm{F}=1.516$, $\mathrm{df}=1,13, \mathrm{p}=0.24$ ). On day 28 there was not sufficient leaf material to extract ATP. When converted to microbial biomass, fungal biomass peaked earlier on the fertilised leaves (Figure 2), but the results were not significantly different in the two treatments (ANOVA: $\mathrm{F}=0.470, \mathrm{df}=1.13, \mathrm{p}=0.51$ ).

Colonisation by macroinvertebrates was fast; maximum richness was attained by day 7 and this plateau was maintained until the end of the study in both treatments (Figure 3). Numbers of taxa colonising fertilised and unfertilised leaf bags were not significantly different (ANOVA: $\mathrm{F}=0.468$, $\mathrm{df}=1,33, \mathrm{p}=0.50$ ). In total, 24 taxonomic groups (family or higher taxonomic level) were identified during the study period, most of them belonging to seven orders of insects (Table 2). The macroinvertebrate community was dominated by the dipterans Simuliidae (31\% in both treatments) and Chironomidae (30 and 29\% in the treatment with and without nutrients, respectively), and by

Table 1. Breakdown rates $(k)$ of fertilised and unfertilised eucalyptus leaves in coarse mesh bags in a Southeastern Brazilian mountain stream. Breakdown rates were estimated by linear regression analysis on $\ln (\mathrm{x})$ transformed data (c.l. $=95 \%$ confidence limit; $r^{2}=$ coefficient of determination).

\begin{tabular}{lccc}
\hline Treatment & $\mathbf{k} \pm \mathbf{c . l .} .\left(\mathbf{d a y}^{-\mathbf{1}}\right)$ & $\mathbf{r}^{\mathbf{2}}$ & $\mathbf{n}$ \\
\hline Fertilised & $-0.1127 \pm 0.0366$ & 0.627 & 26 \\
Unfertilised & $-0.1192 \pm 0.0297$ & 0.758 & 24 \\
\hline
\end{tabular}

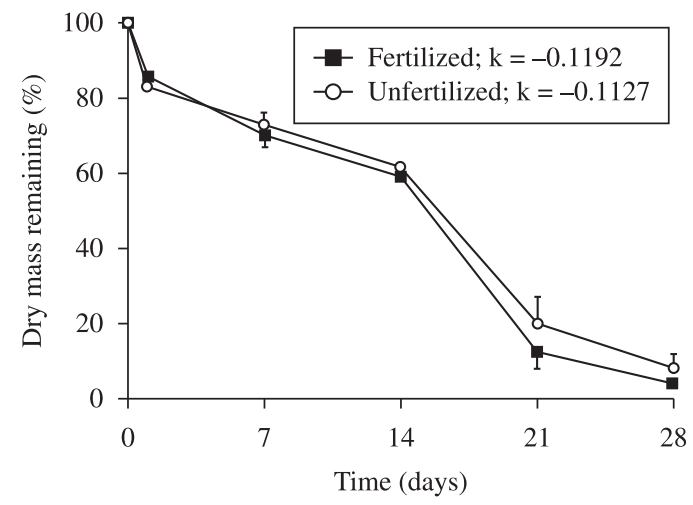

Figure 1. Mass loss of fertilised and unfertilised eucalyptus leaves during decomposition in a Southeastern Brazilian mountain stream (average $\pm 1 \mathrm{SE}$ ). 

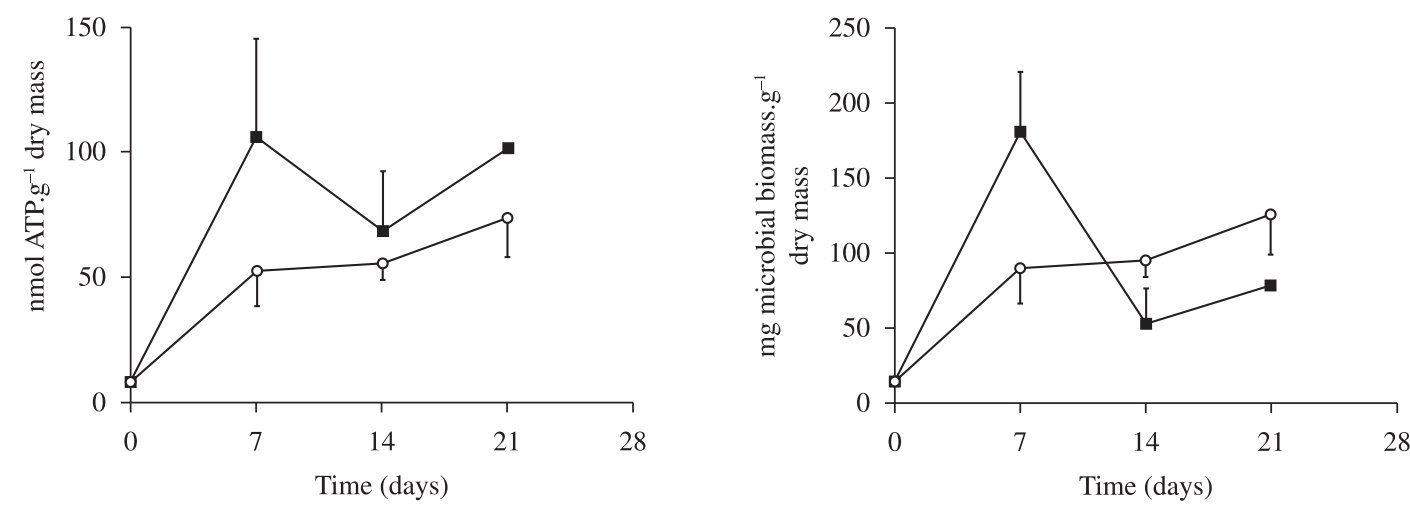

Fertilized $-0-$ Unfertilized

Figure 2. ATP concentrations (topleft) and microbial biomass (bottomright) associated with decomposing leaves of eucalyptus in a Southeastern Brazilian mountain stream (average $\pm 1 \mathrm{SE}$ ). Microbial biomass was estimated assuming that fungi dominate the microbial community up to when ATP concentrations show the first decrease and bacteria dominate afterwards (Abelho, 2009).

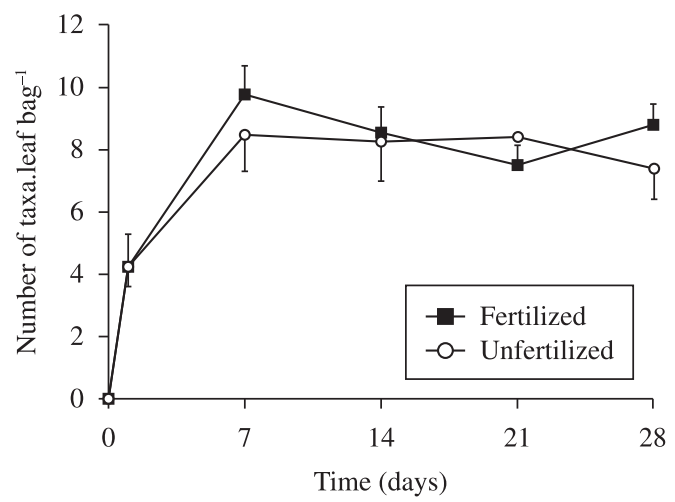

Figure 3. Number of taxa colonising decomposing leaves of eucalyptus in a Southeastern Brazilian mountain stream (average $\pm 1 \mathrm{SE})$.

the caddisfly Hydropsychidae (23 and 21\%). These three families constituted 83 and $81 \%$ of all the invertebrates collected in the leaf bags with and without nutrients, respectively (Table 2 ).

Total invertebrate and chironomid abundance (Figure 4) were higher in the fertilised leaf bags throughout the study, but there were no significant differences between treatments in either total, shredder (Figure 4), collector + scraper, filterer, predator or chironomid abundances (ANOVA: $\mathrm{F}<3.177$, df $=1,33, \mathrm{p}>0.23$ ). Total biomass attained a maximum on day 14 in the fertilised and on day 21 in the unfertilised leaf bags (Figure 4). Again, there were no significant differences between treatments in any of the response variables related to biomass (ANOVA: $\mathrm{F}<1.551$, $\mathrm{df}=1,33, \mathrm{p}>0.22$ ).

The relative abundance of macroinvertebrate functional feeding groups and of Chironomidae (Figure 5) was similar in the fertilised and the unfertilised leaf bags, either as percentage abundance (ANOVA: $\mathrm{F}=0.350$, df $=1,41$, $\mathrm{p}=0.56$ ) or percentage biomass (ANOVA: $\mathrm{F}=1.189$, $\mathrm{df}=1,41, \mathrm{p}=0.28)$. Whereas filterers and Chironomidae numerically dominated in both treatments, in terms of biomass the relative importance of collector + scrapers, predators and shredders increased in relation to Chironomidae (Figure 5).

\section{Discussion}

Contrarily to other studies (e.g. Robinson and Gessner, 2000; Abelho and Graça, 2006), no significant differences were found between fertilised and unfertilised leaf bags in any of the studied response variables. Since nutrient content of the leaves was not measured, it may be that the fertiliser sticks did not increase their nutrient content, but in fact there were on average higher ATP concentrations, total invertebrate and chironomid abundances in the fertilised than in the unfertilised leaves, showing an enhancement at least in some of the leaf bags with nutrient addition (though not significant due to the variation among replicates). It could be that, as suggested by Royer and Minshall (2001), leaf breakdown was not nutrient-limited in the stream, since water nutrient concentrations and temperature were relatively high. Other probable reasons for the lack of effect of fertilisation on breakdown rates are: i) the release of the fertiliser was too fast and did not endure to the end of the experiment; ii) the breakdown rate of the eucalyptus leaves was too fast to allow detection of differences due to fertilisation (see below).

Although not usually considered leaf-shredding invertebrates, chironomids are often the most abundant taxon colonising decomposing leaves (e.g. Gonçalves Jr. et al., 2006; Moretti et al., 2007b), and some authors have found evidence, both in temperate and tropical streams, of chironomids feeding on leaves or on detritus (Henriques-Oliveira et al., 2003; Menéndez et al., 2003; Callisto et al., 2007), concluding that some Chironomidae can use leaf litter as a complementary 
Table 2. Number of individuals (and percentage of total) per taxa collected during the sampling period in fertilised and unfertilised leaf bags.

\begin{tabular}{|c|c|c|c|c|}
\hline \multicolumn{2}{|c|}{ Taxa } & \multirow{2}{*}{$\begin{array}{c}\text { Functional Feeding Group } \\
\text { Predator }\end{array}$} & \multirow{2}{*}{$\begin{array}{c}\text { Fertilised } \\
1\end{array}$} & \multirow{2}{*}{$\frac{\text { Unfertilised }}{2}$} \\
\hline Nematoda & & & & \\
\hline \multirow[t]{2}{*}{ Annelida } & Lumbriculidae & Collector & 0 & 1 \\
\hline & Naididae & Predator & 7 & 1 \\
\hline Hydracarina & & Predator & 0 & 4 \\
\hline \multirow[t]{3}{*}{ Ephemeroptera } & Baetidae & Scraper & 30 & 55 \\
\hline & Leptohypidae & Collector & 92 & 75 \\
\hline & Leptophlebiidae & Shredder & 4 & 5 \\
\hline \multirow[t]{2}{*}{ Plecoptera } & Gryptopterigidae & Shredder & 87 & 92 \\
\hline & Perlidae & Predator & 30 & 23 \\
\hline Heteroptera & Vellidae & Predator & 1 & 0 \\
\hline \multirow[t]{3}{*}{ Coleoptera } & Elmidae & Collector & 70 & 58 \\
\hline & Gyrinidae & Predator & 2 & 0 \\
\hline & Hydrophilidae & Predator & 0 & 1 \\
\hline Megaloptera & Corydalidae & Predator & 1 & 0 \\
\hline \multirow[t]{4}{*}{ Trichoptera } & Hydropsychidae & Filterer & $470(22.9)$ & $365(20.8)$ \\
\hline & Hydroptilidae & Scraper & 2 & 1 \\
\hline & Philipotamidae & Filterer & 9 & 1 \\
\hline & Xiphocentronidae & Collector & 0 & 1 \\
\hline \multirow[t]{7}{*}{ Diptera } & Ceratopogonidae & Predator & 1 & 1 \\
\hline & Chironomidae & (not attributed) & $629(29.7)$ & $510(29.1)$ \\
\hline & Dixidae & Collector & 0 & 2 \\
\hline & Empididae & Predator & 5 & 3 \\
\hline & Scatophagidae & Predator & 2 & 0 \\
\hline & Simuliidae & Filterer & $610(30.6)$ & $550(31.4)$ \\
\hline & Tipulidae & Shredder & 1 & 1 \\
\hline Total abundance & & & 2054 & 1752 \\
\hline
\end{tabular}

food source and that the activities of chironomid larvae may contribute significantly to detritus decomposition. Canhoto and Graça (1999) observed chironomids feeding on decomposing eucalypt leaves in Portugal. In our work, family Chironomidae was not overwhelmingly dominant, but was one of the most abundant taxon, representing 29 and $31 \%$ of all invertebrates, respectively on the unfertilised and on the fertilised leaves. However, the higher average abundances found in fertilised leaf bags did not translate into faster breakdown rates. It may be that they were not in fact feeding on the leaf tissue or that their feeding activity was not enough to translate into faster breakdown rates, although fertilised leaf bags had less mass remaining than unfertilised ones at the end of the experiment.

In comparison with leaf litter typical of the Brazilian Cerrado (Ocotea sp., Myrcia guyanensis, Mirconia chatacea, Protium brasiliense and P. heptaphyllum; $\mathrm{k}>0.0088$ day $^{-1}$ ) decomposing in the same stream under similar circumstances (Moretti et al., 2007a) the breakdown rates of E. camadulensis obtained in this study $\left(\mathrm{k}>0.1127\right.$ day $\left.^{-1}\right)$ were high. Although eucalyptus leaves are usually considered relatively refractory to breakdown due to the high concentrations of secondary compounds and toughness and to the relatively low nutrient contents (e.g., Graça et al., 2002), the vegetation of the Cerrado biome is even tougher and more recalcitrant to biological breakdown (Moretti el al., 2007a). The breakdown rates of eucalyptus obtained in this study were faster than breakdown rates obtained in other studies with leaves of E. grandis (Gonçalves Jr., 2005; Hepp et al., 2009) in Brazilian streams. But these faster breakdown rates were probably more related to the characteristics of the stream rather than to the characteristics of the leaf species, which are similar (Gonçalves Jr., 2005; Moretti, 2009). It could also be that the fast breakdown rates were due to current abrasion, which may enhance decomposition and the loss of particles through the coarse mesh used (Abelho, 2001). The Garcia stream, when compared to the stream studied by Gonçalves Jr. (2005) has higher water temperature and higher nutrient contents, which probably contributed to enhance microbial-related decomposition in this stream. Moreover, this stream has the highest shredder abundances recorded 

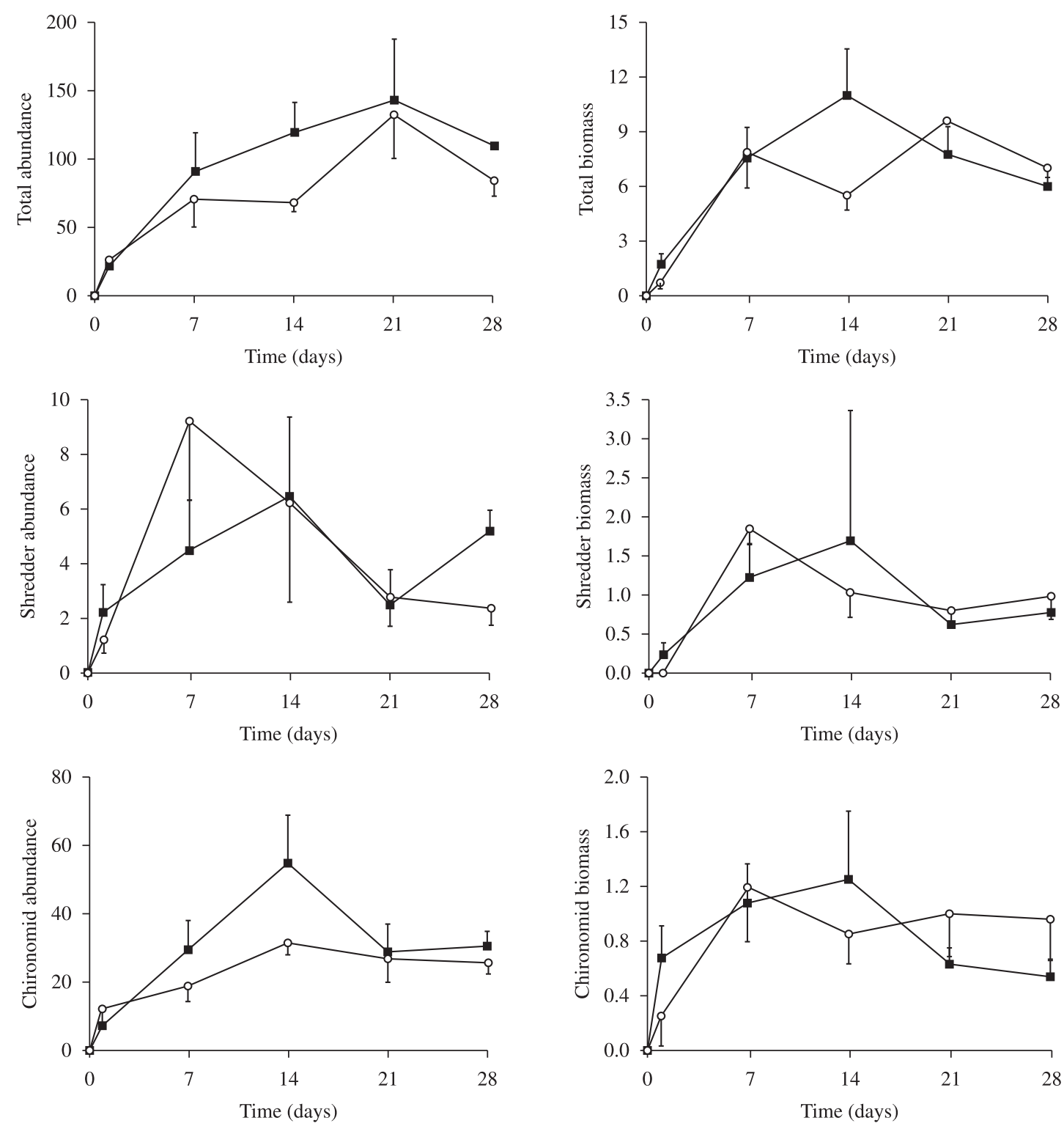

Fertilized $-0-$ Unfertilized

Figure 4. Abundance (number.leaf $\mathrm{bag}^{-1}$; left) and biomass (mg.leaf $\mathrm{bag}^{-1}$; right) of total invertebrates (top), shredders (middle) and Chironomidae (bottom) colonising decomposing eucalyptus leaves in a Southeastern Brazilian mountain stream (average $\pm 1 \mathrm{SE}$ ).

in literature for the Brazilian Cerrado, and Moretti (2009) has shown that the shredder Phylloicus sp. (Trichoptera, Calamoceratidae) prefer feeding on eucalyptus than on leaves of species typical of the Cerrado. If other shredders have the same feeding preferences, the fast decomposing rates observed in fertilised and non-fertilised eucalyptus leaves may have also been due to enhanced feeding activity of the shredders. If breakdown rates of eucalyptus prove to be faster than autochthonous leaf litter, the afforestation with these species may result in the alteration of nutrient dynamics in the Brazilian Cerrado.
Concluding, fertilisation of leaf bags did not significantly increase microbial or invertebrate colonisation of the leaves and did not translate into faster breakdown rates. At this stage, it is not possible to determine if methodological constraints (e.g., coarse mesh, fertilisation pellets) influenced the obtained results and more studies are needed to provide insight on the relationships between nutrient enrichment, microbial and macroinvertebrate colonisation, and decomposition rates. These future studies would elucidate on the effect of nutrient-enrichment on decomposition of other leaf species and in lower-nutrient content streams of the region. 


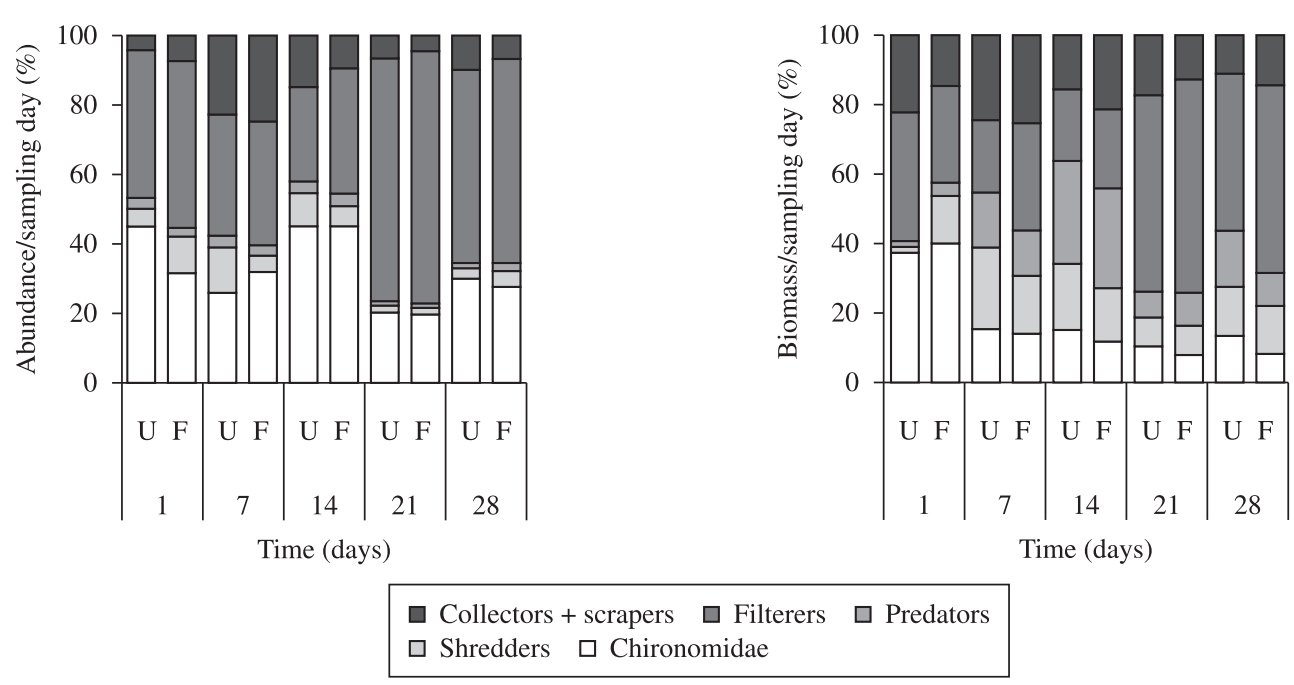

Figure 5. Percentage abundance (top) and percentage biomass (bottom) of functional feeding groups and Chironomidae colonising decomposing eucalyptus leaves in a southeastern Brazilian mountain stream.

Acknowledgements - This work was part of a technicalscientific protocol between Universidade Federal de Minas Gerais (UFMG, Brazil) and Universidade de Coimbra (UC, Portugal), funded by CAPES (Brazil) and FCT (Portugal).

\section{References}

ABELHO, M. and GRAÇA, MAS., 1996. Effects of eucalyptus afforestation on leaf litter dynamics and macroinvertebrate community structure of streams in Central Portugal. Hydrobiologia, vol. 324, p. 195-204.

-, 2006. Effects of nutrient enrichment on decomposition and fungal colonization of sweet chestnut leaves in an Iberian stream (Central Portugal). Hydrobiologia, vol. 560, p. 239-247.

ABELHO, M., 2001. From litterfall to breakdown in streams: a review. TheScientificWorld, vol. 1, p. 656-680.

-, 2005. Extraction and quantification of ATP as a measure of microbial biomass. In GRAÇA, MAS., BÄRLOCHER, F. and GESSNER, MO. (Eds.). Methods to Study Litter Decomposition: A Practical Guide. The Netherlands: Springer, p. 223-229.

-, 2009. ATP and ergosterol as indicators of fungal biomass during leaf decomposition in streams: a comparative study. International Review of Hydrobiology, vol. 94, no. 1, p. 3-15.

American Public Health Association - APHA, 1998. Standard methods for the examination of water and wastewater. $20^{\text {th }}$ ed. Washington, D.C.: APHA, 1220 p.

BOULTON, AJ. and BOON, PI., 1991. A review of methodology used to measure leaf litter decomposition in lotic environments: time to turn over an old leaf? Australian Journal of Marine and Freshwater Research, vol. 42, p. 1-43.

CALLISTO, M., GONÇALVES Jr., JF. and GRAÇA, MAS., 2007. Leaf litter as a possible food source for chironomids (Diptera) in Brazilian and Portuguese headwater streams. Revista Brasileira de Zoologia, vol. 24, no. 2, p. 442-448.

CANHOTO, C. and GRAÇA, MAS., 1996. Decomposition of Eucalyptus globulus leaves and three native leaf species (Alnus glutinosa, Castanea sativa and Quercus faginea) in a Portuguese low order stream. Hydrobiologia, vol. 333, p. 79-85.

-, 1999. Leaf barriers to fungal colonization and shredders (Tipula lateralis) consumption of decomposing Eucalyptus globulus. Microbial Ecology, vol. 37, p. 163-172.

COSTA, C., IDE, S. and SIMONKA, SE. (Eds.), 2006. Insetos imaturos - metamorfose e identificação. Ribeirão Preto: Holos Editora, 249 p.

GIULIETTI, AM., MENEZES, NA., PIRANI, JR., MEGURO, M. and VANDERLEY, MGL., 1987. Flora da Serra do Cipó: caracterização e lista de espécies. Boletim de Botânica, vol. 9, p. 1-151.

GONÇALVES Jr., JF., 2005. Decomposição de detritos foliares em riachos: composição química, invertebrados e microorganismos. Belo Horizonte: Universidade Federal de Minas Gerais - UFMG. [PhD Thesis].

GONÇALVES Jr., JF., FRANÇA, JS., MEDEIROS, AO., ROSA, CA. and CALLISTO, M., 2006. Leaf breakdown in a tropical stream. International Review of Hydrobiology, vol. 91, no. 2, p. $164-177$.

GONÇALVES Jr., JF., GRAÇA, MAS. and CALLISTO, M., 2007. Litter decomposition in a Cerrado savannah stream is retarded by leaf toughness, low dissolved nutrients and a low density of shredders. Freshwater Biology, vol. 52, p. 1440-1451.

GRAÇA, MAS., POZO, J., CANHOTO, C. and ELOSEGI, A., 2002. Effects of Eucalyptus globulus plantations on detritus, decomposers and detritivores. TheScientificWorld Journal, vol. 2, p. 1173-1185.

HENRIQUES-OLIVEIRA, AL., NESSIMIAN, JL. and DORVILLÉ, LFM., 2003. Feeding habits of Chironomid larvae (Insecta: Diptera) from a stream in the Floresta da Tijuca, Rio de Janeiro, Brazil. Brazilian Journal of Biology, vol. 63, p. 269-281.

HEPP, LU., DELANORA, R. and TREVISAN, A., 2009. Compostos secundários durante a decomposição foliar de espécies arbóreas em um riacho do sul do Brasil. Acta Botânica Brasileira, vol. 23, no. 2, p. 407-413. 
KLINK, CA. and MACHADO, RB., 2005. Conservation of the Brazilian Cerrado. Conservation Biology, vol. 19, p. 707-713.

MENÉNDEZ, M., HERNÁNDEZ, O. and COMÍN, FA., 2003. Seasonal comparisons of leaf processing rates in two Mediterranean rivers with different nutrient availability. Hydrobiologia, vol. 495, p. 159-169.

MERRITT, RW. and CUMMINS KW., 1996. An introduction to the aquatic insects of North America. $3^{\text {th }}$ ed. Dubuque, Iowa: Kendall/Hunt Publishing Company, 361 p.

MORETTI, MS., 2005. Decomposição de detritos foliares e sua colonização por invertebrados aquáticos em dois córregos na Cadeia do Espinhaço (MG). Belo Horizonte: Universidade Federal de Minas Gerais - UFMG. [Master thesis].

-., 2009. Comportamento de larvas de Phylloicus sp. (Trichoptera, Calamoceratidae): um fragmentador característico de córregos neotropicais. Belo Horizonte: Universidade Federal de Minas Gerais - UFMG, 77 p. [Tese de Doutorado].

MORETTI, MS., GONÇALVES Jr., JF. and CALLISTO, M., 2007a. Leaf breakdown in two tropical streams: differences between single and mixed species packs. Limnologica, vol. 37, p. $250-258$

MORETTI, MS., GONÇALVES Jr., JF., LIGEIRO, R. and CALLISTO, M., 2007b. Invertebrates colonization on native tree leaves in a neotropical stream (Brazil). International Review of Hydrobiology, vol. 92, no. 2, p. 199-210.

PÉREZ, GR., 1988. Guía para el estudio de los macroinvertebrados acuáticos del Departamento de Antioquia. Bogotá: Fondo Fen Colombia, Conciencias, Universidad de Antioquia, 217 p.

RIBAS, ACA., TANAKA, MO. and DE SOUZA, ALT., 2006. Evaluation of macrofaunal effects on leaf litter breakdown rates in aquatic and terrestrial habitats. Austral Ecology, vol. 31, p. $783-790$

ROBINSON, CT. and GESSNER, MO., 2000. Nutrient addition accelerates leaf breakdown in an alpine springbrook. Oecologia, vol. 122, p. 258-263.

ROYER, TV. and MINSHALL, JW., 2001. Effects of nutrient enrichment and leaf quality on the breakdown of leaves in a hardwater stream. Freshwater Biology, vol. 46, p. 603-610. 